Bangladesh J. Zool. 49 (1): 35-46, 2021

ISSN: 0304-9027

eISSN: $2408-8455$

\title{
OCCURRENCE OF ENDOPARASITES IN DOMESTIC FOWLS (GALLUS GALLUS) AND DUCKS (ANAS PLATYRHYNCHOS)
}

\author{
Hamida Khanum*, Sharmin Musa, Monirul Islam \\ Romana Akter and Fahmida Sarker \\ Department of Zoology, University of Dhaka, Dhaka 1000, Bangladesh
}

\begin{abstract}
A comparative study was carried out to investigate the gastrointestinal helminth infection in domestic fowls Gallus gallus (30 specimens) and ducks Anas platyrhynchos (30 specimen). A total of 1610 helminth parasites of eight species from three taxonomic classes were recovered and identified from the different parts of alimentary canal. Among the parasitic group the cestodes were turned out to be predominant with a prevalence of $50.93 \%$ (820) whereas, the rate was $27.97 \%(450)$ and $21.19 \%$ (340) in nematodes and trematodes, respectively. The prevalence of parasites species were Ascaridia galli (80\%), Echinostoma revolutum (73.33\%), Raillientina echinobothrida (53.33\%), Echinoparyphium recurvatum (53.33\%), Cotugnia digonophora (50\%), Amoebotaenia sphenoids (30\%), Ascaridia hermaphoridita (43.33\%) and Hymenolepis cantania (26.67\%). The rate of infestation was higher $(90 \%)$ in fowls than in ducks $(80 \%)$ and the intensity of infections was slightly higher in ducks 31.67 (31.48 in domestic fowls). In both domestic fowls and ducks, cestode parasites were most dominant, and prevalence $183.33 \%$ and $16.80 \pm 4.31)$ and intensity were lower in fowls than in ducks $(76.67 \%$ and $17.39 \pm$ 4.2 2). Highest rate of infestation was observed in summer both in fowl $(81.82 \%)$ and duck $(70 \%)$ while, winter was associated with peak intensity of parasites in fowl (46.67) and in duck (44.28) observed in summer. The prevalence of parasites was higher in caecum of both domestic fowls and ducks.
\end{abstract}

Key words: Gallus gallus, Anas platyrhynchos, infestation, helminths and seasons

\section{INTRODUCTION}

Properties of the environment determines the diversity of species in a given habitat. (Hassouni and Belghyti 2006, Molla et al. 2012). Pattern in the diversity of parasites may be associated with host and parasites' characteristics and also their environment. Being one of the principal sources of meat and eggs, chicken and duck has become a crucial part of the poultry industry and are providing $37 \%$ of total animal protein source for Bangladesh people (Islam et al. 2013).

*Author for Correspondence: <hamida_khanum@yahoo.com>

(a2021 Zoological Society of Bangladesh DOI: https://doi.org/10.3329/bjz.v49i1.53680 
However production can be reduced due to various diseases which include parasitic, viral and bacterial infections (Ojok 1993). According to Jabbar et al. (2007) poultry animals are mostly infected with parasites, where, endoparasitic infections are caused by helminths, protozoans, viruses, and arthropods ((Rabbi et al. 1976; Magwisha et al. 2002; Mulder 2013, Shinde et el. 2009). Quality and quantity of meat as well as production and health of poultry animals can be seriously affected by intestinal parasitic helminthes.

Malnutrition, reduced feed conversion ratio, loss of weight, reduced fecundity and death in juvenile birds may cause substantial damage and huge financial loss to the poultry industry. Khanum (1997) and Akhter (1987) performed studies on nematode and trematode parasites. Qadir (1979) and Islam et al. (1988) in Bangladesh performed great amount of studies. Cestode seems to be dominant parasites of poultry according to various studies. Soulsby (1982) reported that among cestods parasites from hymenolepid family is dominant. Scavenging feeding on vector hosts might be the reason for cestode burden.

Parasitic infections of these domestic birds are mostly associated with their food habit. Chickens are generally scavangers and feed on grains, insects, and worms while, food diversity is observed in domestic ducks which eat a variety of animal and plant materials such as aquatic insects, molluscs, worms, small amphibians, weeds, grasses. These food items can serve as intermediate hosts of parasite larvae of trematode and cestode. Besides, climatic factors like temperature and humidity also affect the prevalence and intensity of these parasitic helminthes (Elahi et al. 2014). Khanum et al. (1997) reported trematode and nematode parasite are prevalent in domestic fowl where. Begum et al. (2019) observed seven species of ectoparasite and thirteen species of endoparasite in domestic ducks. Among the two selected hosts, fowls were terrestrial birds while ducks were habituated to aquatic modes of life and consequently their feeding habits were also completely different. Fowls are generally scavanger and feed on grains, insects and worms. Traditionally reared domestic chicken reared in backyard, in a free-range poultry production systems has a variety of feeding habits which includes maggots, insects, cow/buffalo dung, kitchen waste, viscera of other animals and faeces which are carrier of parasites which escalates the degree of contact with potential disease causing organisms (Adang et al. 2008). On contrary, the domestic ducks are voracious eaters eating a variety of animal and plant materials such as aquatic insects, molluscs, worms, small amphibians, weeds and grasses which serve as intermediate host of trematode and cestode parasites. 


\section{MATERIAL AND METHODS}

A total of 60 animals: 30 domestic Fowls (Gallus gallus) and 30 domestic Ducks (Anas platyrhynchos) were analyzed in the present study. They were collected from local markets of Dhaka city in a regular interval from March 2018 to February 2019. The laboratory examination was conducted in the parasitology laboratory, Department of Zoology, University of Dhaka. After measuring and differentiating the length, weight and sex of the fowls and ducks, the animals were dissected. The gastro-intestinal tract was differentiated into esophagus, crop, proventriculus, gizzard, duodenum, small intestine, caecum and rectum.

Fixation, identification and Preservation of parasites: All the collected worms were washed in saline solution. Cestode parasites were fixed with boiled fixative Alcohol Formal Acetic (A.F.A), preserved in $70 \%$ ethyl alcohol with a few drops of glycerin added (Cable 1957). Large specimens were pressed between two glass slides, then a few drops of fixative or corrosive acetic acid was added, followed by dipping into fixing fluid and then preserved in $70 \%$ Ethyl alcohol. Large nematodes were fixed glacial acetic acid, and then preserved in $70 \%$ ethyl alcohol.

According to the objectives of the present investigation, parasites of domestic fowls and ducks and the prevalence, intensity and the organal distribution of parasites in different sexes, seasons were also investigated. For identification, the worms were dehydrated in an ethanol series (70\%-100\%) and the helminths were cleared in Lacto-phenol, stained in Borax carmine, upgrading with alkohols and mounted in DPX. Methodology fixation of both cestode and trematode parasite was similar. The parasite species were identified according to Yamaguti $(1958,1961 ; 1961)$ and Soulsby (1982).

\section{RESULTS AND DISCUSSION}

A total of 1610 helminth parasites of eight species from three taxonomic classes were recovered and identified from the different parts of alimentary canal of domestic fowls and ducks. Out of 1610 parasites, 820 (50.93\%) were cestodes, $450(27.97 \%)$ were nematodes and $340(21.19 \%)$ were trematodes.

Prevalence and intensity of helminth parasites in domestic fowl: Altogether four species of endoparasites were identified from fowls and these species were Ascaridia galli (80\%), Echinostoma revolutum (73.3\%), Raillientina echinobothrida (53.33\%) and Amoebotaenia sphenoids (30\%) (Table 1). The prevalence of infection in total host was $90 \%$ and it was higher $(94.44 \%)$ in male than female 
(83.33\%). In fowls the intensity of infestation in male host was 28.88 and in female host 35.90 .

Prevalence and intensity of helminth parasites in duck: Four species of helminth parasites were identified from ducks and these species were Echinoparyphium recurvatum (53.33\%), Cotugnia digonophora (50\%), Ascaridia galli (43.33\%) and Hymenolepis cantania (26.67\%) (Table 2). The prevalence of infection in total host was $80 \%$ but the prevalence was higher in female host $(85.71 \%)$ than in male host $(75 \%)$. Similarly the intensity of infestation was higher in female host (34.17) than in male host (29.17).

Comparison of helminth infestation between domestic fowl and duck: The prevalence of infestation was higher (90\%) in fowls than in ducks $(80 \%)$ while the intensity found higher in ducks 31.67 (fowls: 31.48). Both the domestic fowls and ducks were mostly infected with the cestode parasite whereas the prevalence and intensity was higher in fowls (83.33\% and $16.80 \pm 4.31)$ than in ducks (76.67\% and $17.39 \pm 4.2$ 2) (Table 1and 2). Similar result was observed by Farjana et al. (2008) where the intensity of cestodes was higher in ducks than in trematodes and nematodes.

Table-1. Prevalence and intensity of infestation in male and female host by species wise helminth in G. gallus (Fowls)

\begin{tabular}{|c|c|c|c|c|c|c|c|c|c|c|}
\hline \multirow[t]{2}{*}{$\begin{array}{l}\text { Name of the } \\
\text { parasites }\end{array}$} & \multicolumn{2}{|c|}{$\begin{array}{c}\text { No. of host } \\
\text { examined }\end{array}$} & \multicolumn{2}{|c|}{$\begin{array}{c}\text { No. of infected } \\
\text { host }\end{array}$} & \multicolumn{2}{|c|}{ Prevalence (\%) } & \multicolumn{2}{|c|}{$\begin{array}{l}\text { Total no. of } \\
\text { parasites }\end{array}$} & \multicolumn{2}{|c|}{ Intensity } \\
\hline & Male & Female & Male & Female & Male & Female & Male & Female & Male & Female \\
\hline $\begin{array}{l}\text { Raillientina } \\
\text { echinobothria }\end{array}$ & 18 & 12 & 6 & 10 & 39.3 & 83.3 & 70 & 180 & $\begin{array}{l}11.7 \\
\pm 1.87\end{array}$ & $\begin{array}{l}18.0 \\
\pm 1.67\end{array}$ \\
\hline $\begin{array}{l}\text { Amoebotaeni } \\
\text { a sphenoids }\end{array}$ & 18 & 12 & 5 & 4 & 27.2 & 33.3 & 90 & 80 & $\begin{array}{l}18.0 \\
\pm 2.09\end{array}$ & $\begin{array}{l}20 \\
\pm 2.17\end{array}$ \\
\hline $\begin{array}{l}\text { Ascaridia } \\
\text { galli }\end{array}$ & 18 & 12 & 14 & 10 & 77.8 & 83.3 & 120 & 90 & $\begin{array}{l}8.6 \\
\pm 2.37\end{array}$ & $\begin{array}{l}9.0 \\
\pm 2.91\end{array}$ \\
\hline $\begin{array}{l}\text { Echinostoma } \\
\text { revolutum }\end{array}$ & 18 & 12 & 12 & 10 & 66.7 & 83.3 & 140 & 80 & $\begin{array}{l}11.7 \\
\pm 3.12\end{array}$ & $\begin{array}{l}8 \\
\pm 2.97\end{array}$ \\
\hline
\end{tabular}

Table-2. : Prevalence and intensity of infestation in male and female host by species wise helminths in Anas platyrhynchos (Ducks)

\begin{tabular}{|c|c|c|c|c|c|c|c|c|c|c|}
\hline \multirow[t]{2}{*}{$\begin{array}{l}\text { Name of the } \\
\text { parasites }\end{array}$} & \multicolumn{2}{|c|}{$\begin{array}{c}\text { No. of host } \\
\text { examined }\end{array}$} & \multicolumn{2}{|c|}{$\begin{array}{c}\text { No. of infected } \\
\text { host }\end{array}$} & \multicolumn{2}{|c|}{ Prevalence (\%) } & \multicolumn{2}{|c|}{$\begin{array}{l}\text { Total no. of } \\
\text { parasites }\end{array}$} & \multicolumn{2}{|c|}{ Intensity } \\
\hline & Male & Female & Male & Female & Male & Female & Male & Female & Male & Female \\
\hline $\begin{array}{l}\text { Hymenolepis } \\
\text { cantania }\end{array}$ & 16 & 14 & 5 & 3 & 31.2 & 21.4 & 100 & 50 & $\begin{array}{c}20 \\
\pm 1.41\end{array}$ & $\begin{array}{c}16.7 \\
\pm 0.47\end{array}$ \\
\hline $\begin{array}{l}\text { Cotugnia } \\
\text { digonophora }\end{array}$ & 16 & 14 & 10 & 5 & 62.5 & 35.7 & 175 & 75 & $\begin{array}{c}17.5 \\
\pm 2.06\end{array}$ & $\begin{array}{c}15 \\
\pm 1.93\end{array}$ \\
\hline $\begin{array}{l}\text { Ascaridia } \\
\text { hermophoridia }\end{array}$ & 16 & 14 & 8 & 5 & 50.0 & 35.7 & 180 & 60 & $\begin{array}{c}22.5 \\
\pm 2.21\end{array}$ & $\begin{array}{c}12 \\
\pm 1.12\end{array}$ \\
\hline $\begin{array}{l}\text { Ascaridia galli } \\
\text { (female) }\end{array}$ & 16 & 14 & 3 & 2 & 18.7 & 14.3 & 25 & 15 & $\begin{array}{c}8.3 \\
\pm 1.06\end{array}$ & $\begin{array}{c}7.5 \\
\pm 0.24\end{array}$ \\
\hline $\begin{array}{l}\text { Echinoparyphium } \\
\text { recurvatum }\end{array}$ & 16 & 14 & 9 & 7 & 56.2 & 50.0 & 50 & 30 & $\begin{array}{c}5.5 \\
\pm 1.54\end{array}$ & $\begin{array}{c}4.3 \\
\pm 0.65\end{array}$ \\
\hline
\end{tabular}

Raillietina echinobothrida was the dominant parasite species of fowl and its prevalence and intensity was higher in female $(83.3 \%, 18.0 \pm 1.67)$ than in male $(39.3 \%, 11.7 \pm 1.87)$. The occurrence of Ascaridia galli and Echinostoma 
revolutum were also significantly higher but the prevalence and intensity was higher in male (Table 03). In case of duck host Cotugnia digonophora was the most prevalent species and in contrast to the fowl host its prevalence and intensity was higher in male $(62.5 \%, 17.5 \pm 2.06)$ (Table 1 and 2).

Organal distribution of helminth parasites in domestic fowl: In domestic fowls, from 30 hosts 27 were infected with 850 helminth parasites of which 419 were found in caecum, 296 were found in intestine and 135 were found in duodenum. The prevalence of infestation was $90 \%$ in caecum, 50\% in intestine and $40 \%$ in duodenum. Intensity in the caecum, intestine and duodenum was $(15.19,19.73,11.25)$ respectively. Echinostoma revolutum $(100 \%)$ was the prevalent species in the caecum where intestine was mostly infected with

\begin{tabular}{|c|c|c|c|c|c|c|c|c|}
\hline \multirow{2}{*}{ Host } & \multirow[t]{2}{*}{ Name of parasites } & \multirow{2}{*}{$\begin{array}{l}\text { Total no. } \\
\text { of worm } \\
\text { collected }\end{array}$} & \multicolumn{2}{|c|}{ Caecum } & \multicolumn{2}{|c|}{ Intestine } & \multicolumn{2}{|c|}{ Duodenum } \\
\hline & & & $\begin{array}{l}\text { No. of } \\
\text { worms }\end{array}$ & $\begin{array}{c}\text { Perce. } \\
(\%)\end{array}$ & $\begin{array}{l}\text { No. of } \\
\text { worms }\end{array}$ & $\begin{array}{l}\text { Perce. } \\
(\%)\end{array}$ & $\begin{array}{c}\text { No. of } \\
\text { worms }\end{array}$ & $\begin{array}{c}\text { Perce. } \\
(\%)\end{array}$ \\
\hline \multirow{6}{*}{ Fowls } & $\begin{array}{l}\text { Raillientina } \\
\text { echinobothrida }\end{array}$ & 236 & - & - & 236 & $100 \%$ & - & - \\
\hline & $\begin{array}{l}\text { Amoebotaenia } \\
\text { sphenoids }\end{array}$ & 100 & - & - & - & - & 100 & $100 \%$ \\
\hline & Ascaridia galli & 95 & - & - & 60 & $63.16 \%$ & 35 & $36.84 \%$ \\
\hline & $\begin{array}{l}\text { Echinostoma } \\
\text { revolutum }\end{array}$ & 419 & 419 & $100 \%$ & - & - & - & - \\
\hline & $\begin{array}{l}\text { Cotugnia } \\
\text { digonophora }\end{array}$ & 70 & - & - & 70 & $100 \%$ & - & - \\
\hline & $\begin{array}{l}\text { Hymenolepis } \\
\text { cantania }\end{array}$ & 210 & 210 & $100 \%$ & - & - & - & - \\
\hline \multirow[b]{2}{*}{ Ducks } & $\begin{array}{l}\text { Ascaridia } \\
\text { hermaphoridita }\end{array}$ & 75 & - & - & 30 & $38.96 \%$ & 45 & $58.44 \%$ \\
\hline & $\begin{array}{l}\text { Ascaridia galli } \\
\text { (female) }\end{array}$ & 74 & - & - & 29 & $39.19 \%$ & 35 & $47.29 \%$ \\
\hline
\end{tabular}

Raillientina echinobothrida (100\%) and Ascaridia galli (63.16\%) and duodenum with Amoebotaenia sphenoids (100\%) (Table 3).

Organal distribution of helminth parasites in duck: In ducks from 30 hosts 24 were infected with 760 helminth parasites of which 541 were found in caecum, 119 were found in intestine and 100 were found in duodenum. The prevalence of infestation was $80 \%$ in caecum, $46.67 \%$ in intestine and $26.67 \%$ in duodenum. Intensity in the caecum, intestine and duodenum was $(22.54,8.50$, 12.50) respectively. Both Hymenolepis cantania (100\%) and Echinoparyphium recurvatum $(100 \%)$ were dominant parasite species in caecum. Two species Cotugnia digonophora (100\%) and Ascaridia galli (39.6\%) were recovered from intestine and the duodenum was infected with Ascaridia galli (53.7\%) (Table 3).

In the present investigation, among the eight observed species 4 belonged to the cestode, 3 to nematode and 1 to trematode. Only the Ascaridia galli species 
was common in both groups of host. All the parasites collected from the lower part of alimentary canal. Parasite was not present in upper part of alimentary

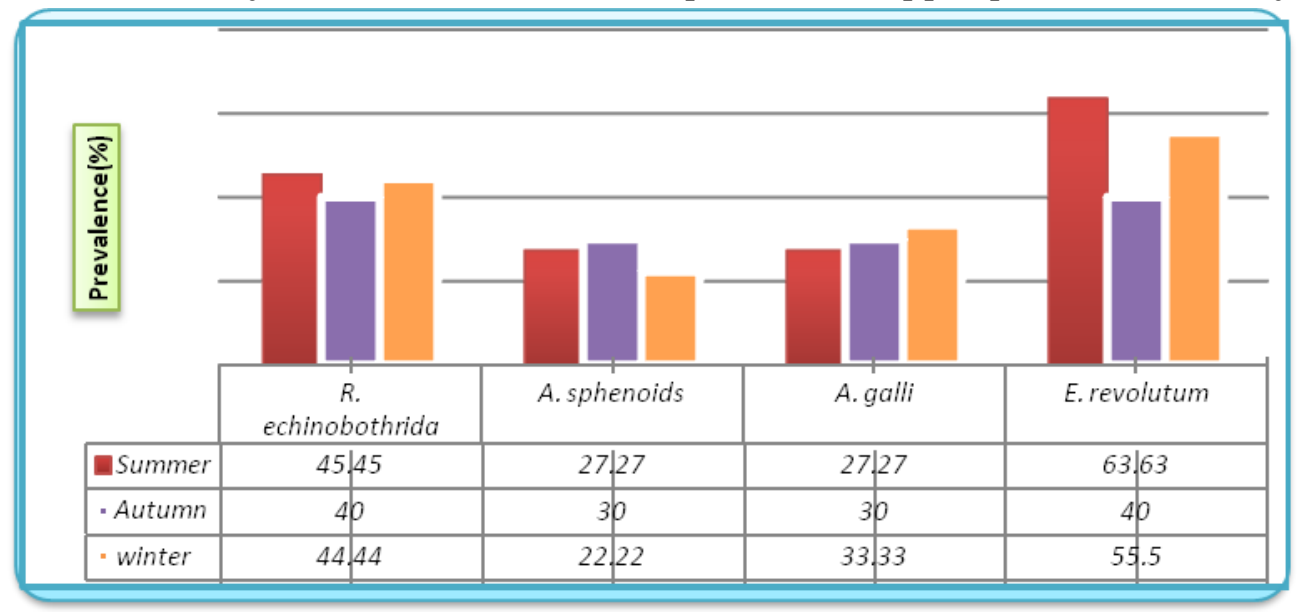

Fig.1: Prevalence of helminth species in three seasons in fowls.

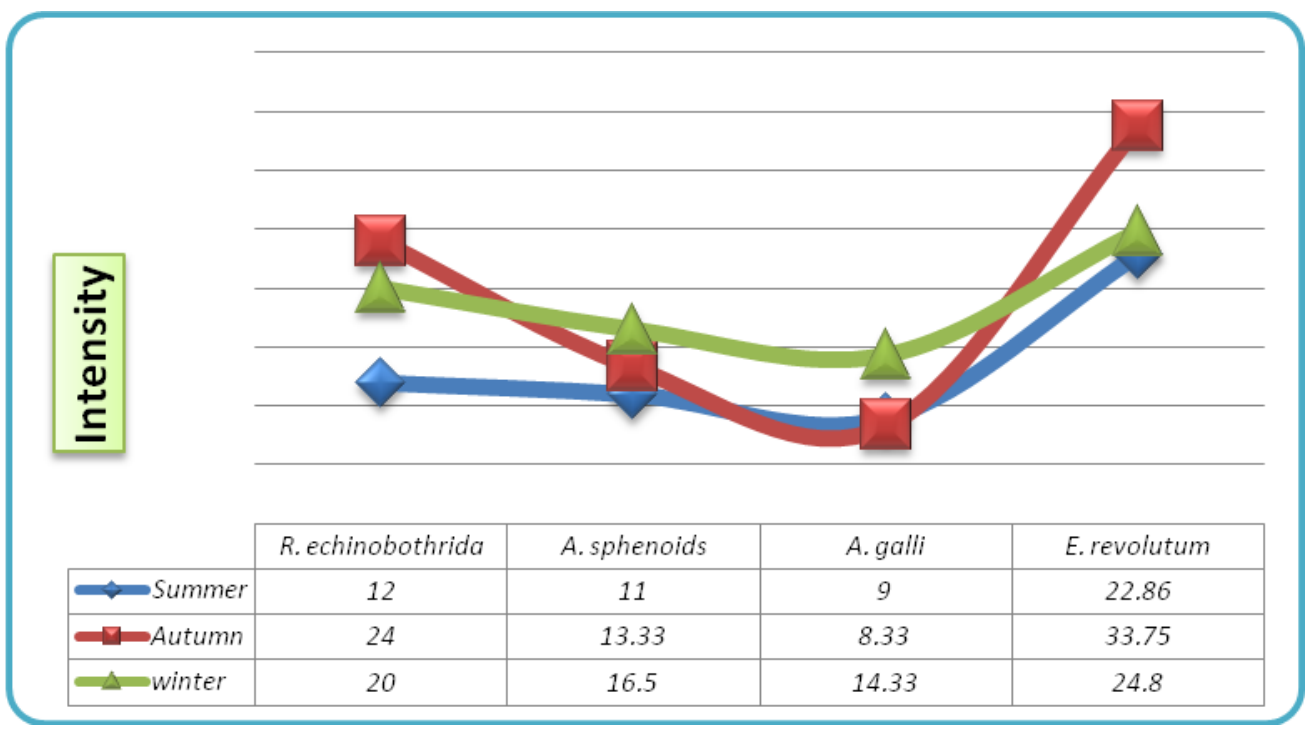

Fig. 2: Intensity of helminth species in three seasons in fowls.

canal such as oesophagus, crops, proventiculus and gizzard while, twenty one species of helminthes from different parts of the digestive track except from crop were recorded by Khanum et al. (1997). Lack of parasite in crop and gizzard indicated the inauspicious ambience of these regions (filled with grains and stone) that prevent their establishment there. In domestic fowl prevalence of 
A. galli was higher (80\%) than that of $A$. sphenoids, and E. revolutum but the intensity was highest (18.89) in A. sphenoids. Three different types of poultry

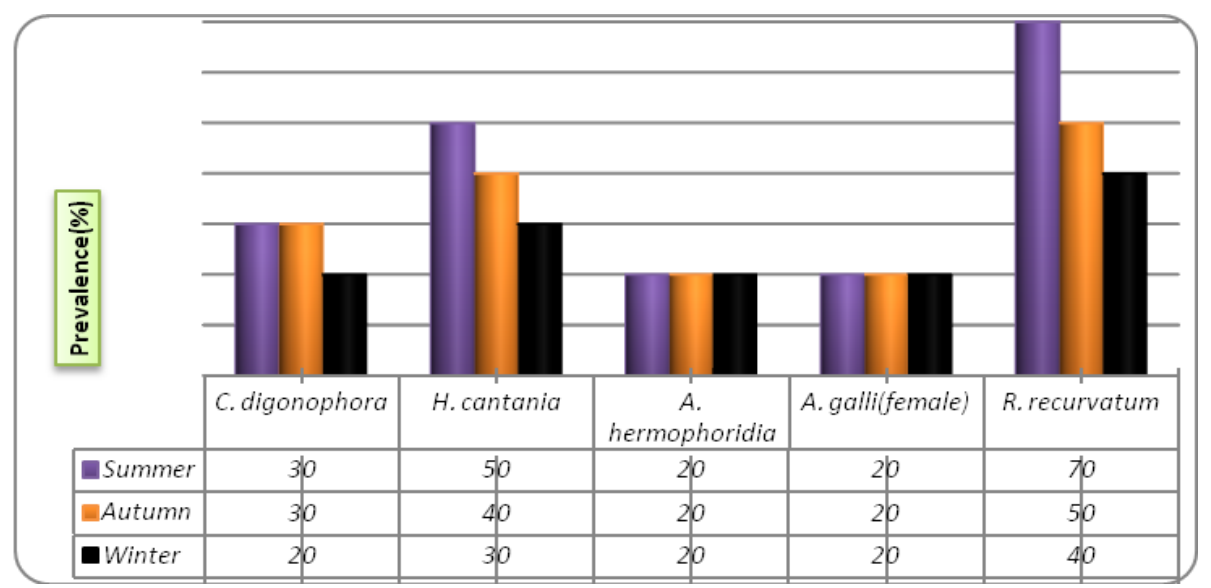

Fig.3: Prevalence of helminth species in three seasons in ducks.

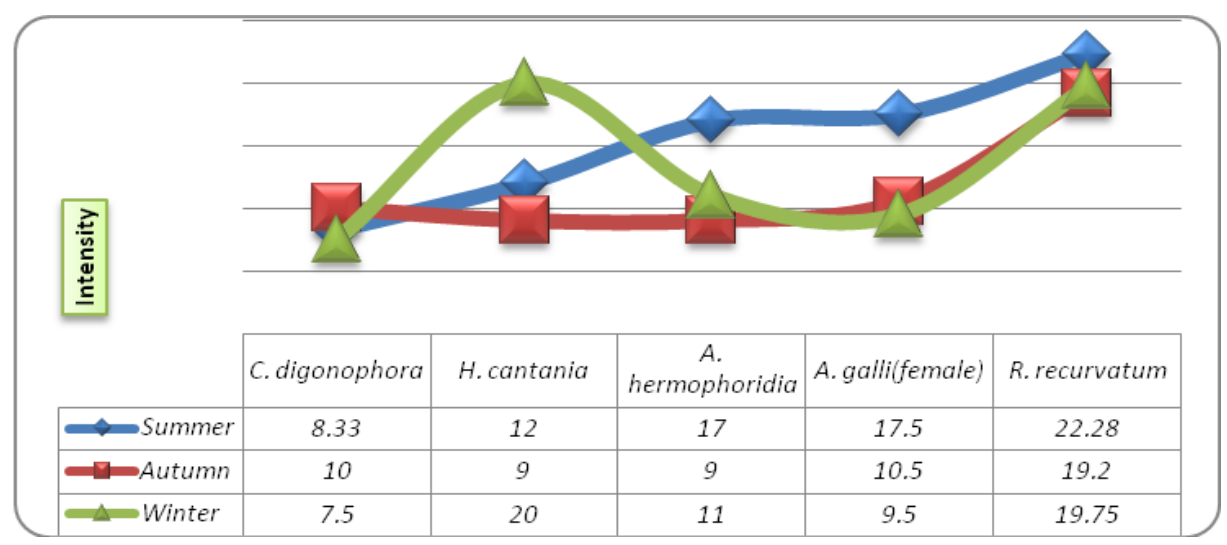

Fig.4: Intensity of helminth species in three seasons in ducks.

such as Broiler, layer and backyard indigenous chickens were compared for gastrointestinal helminths parasitic infection and backyard poultry $(100 \%)$ had highest infection followed by layer $(48.75 \%)$ and broiler $(3.75 \%)$ and the prevalence of $R$. tetragona (100\%) was the highest followed by that of A. galli $(87.50 \%)$ and $H$. gallinarum $(80 \%)$. Overall prevalence of $100 \%$, with a mean intensity of infection of 124 parasites per chicken (Gallus gallus domesticus) (Linnaeus, 1758) were reported by Yousfi and Senouci (2013). 
The most prevalent cestode was Raillietina echinobothrida (85.09\%), nematode: Heterakis gallinarum $(78.07 \%)$ and trematode: Postharmostomum gallinum (18.42\%).

Regarding the distribution of helminth parasites were observed in the small intestine, duodenum and caecum, among 27 infected fowls, both the prevalence and intensity was higher in caecum $(90 \%, 15.51)$ followed by intestine $(50 \%$, 19.73) and duodenum $(40 \%, 11.25)$ (Table 05). The predominant species in caecum, intestine and duodenum was Echinostoma revolutum, Raillientina echinobothrida and Amoebotaenia sphenoids respectively (Table 3). Among 30 ducks, 24 were infected with 760 helminth parasites and the prevalence of infestation was higher in caecum $(80 \%, n=541)$ than in intestine $(46.67 \%$, $\mathrm{n}=119)$ and duodenum (26.67\%, $\mathrm{n}=100)$. Caecum was mostly infected with Echinoparyphium recurvatum and Hymenolepis cantania. The rate of intensity was $22.54,8.50$ and 12.50 in caecum, intestine and duodenum respectively (Table 4). Male were mostly infected with C. digonophora (62.5\%) and female were with E. recurvatum (50\%). While, Musa et al. (2012) observed higher prevalence and intensity in small intestine $(80 \%, 19)$ than in the large intestine and caecum $(10 \%, 16)$. The intensity was higher in female (24.4) than male (15.33). In another study Ahmed (1969) reported 66\% of parasites from alimentary canal. The nematodes were higher than cestodes by about $20 \%$ in duodenum, ileum and colon.

Seasonal prevalence and intensity by each species of helminths in fowl: Different parasites show different prevalence and intensity of infestation in different seasons. In domestic fowls, highest prevalence $(45.45 \%)$ of $R$. echinobothrida infestation was observed in summer while, Intensity of $R$. echinobothrida was highest (24) in autumn. In case of $A$. sphenoids, highest prevalence $(30 \%)$ was observed in autumn (Figure 1) and lowest prevalence $(22.22 \%)$ was observed in winter. Intensity of $A$. sphenoids was highest (16.50) in winter and lowest (11) in summer (Fig. 2). In A. galli, prevalence was observed highest (33.33\%) in winter and highest Intensity (14.33) was observed in winter. In $E$. revolutum highest prevalence $(63.33 \%)$ was observed in summer and highest Intensity (33.75) of E. revolutum was observed in autumn (Fig. 1 and 2).

Seasonal prevalence and intensity by each species of helminths in ducks: In ducks, C. digonophora showed highest prevalence (30\%) in summer and highest intensity (10) in autumn. In case of $H$. cantania highest prevalence $(50 \%)$ was found in summer and intensity of infestation was highest (20) in winter (Figure 3 and 4). In case of $A$. hermophoridia, prevalence (20\%) was same in summer, autumn and autumn, while, Intensity was highest (17.5) in summer. In $E$. recurvatum the highest prevalence $(70 \%)$ was observed in summer and intensity 
was highest (22.28) in summer (Fig. 3 and 4).

Predominant cestode infections in both of the hosts (domestic ducks and fowls) indicate the contamination of natural diet (Eom and Rim 1984, Basu, 1912). Frequent exposure to the natural environment, feeding habits and unhygienic living conditions make them vulnerable to different kinds of helminth infections (Puttalakshmamma et al. 2008). Serious health conditions are attributed to these infections which eventually affect the total protein content of the host. In addition to the health consequences it also influences the economy of the country. Besides, Parasitic infection also offers threat to the endanger birds (Qadir, 1979).

Different kinds of parasitic diseases caused by infection by endoparasites shows symptoms like retarded growth, abnormal weight loss, reduced egg production, mucous diarrhoea, anorexia, anaemia, weakness, paralysis and death (Nair and Nadakal 1981).

In socio-economically underdeveloped countries parasitism causes serious mortality and morbidity. Aside from human health livestock, poultry, fishes and crops are also affected by these types of parasites. In Bangladesh parasitic infections are the major obstacles for the development of poultry, livestock, fisheries and agriculture industry (Yadav and Tandon 1991). Among the most commonly kept poultry like chickens (Gallus sp.), ducks (Carina sp.), geese (Anser sp.) and turkeys (Melegris sp.) chickens (Gallus domesticus) are most popular.

\section{CONCLUSION}

This study concludes that the fowls and ducks have high parasitic infestation. Duck are exposed to natural environment and consume a wide variety of food items because of their aquatic and free ranged nature. They ingest different food items from aquatic environment which harbor intermediate host of larval stages of different parasites and become easily infected. The present comparative study provides an ambiguous view on variation of parasite composition in these domestic birds. If the traditional poultry raisers in rural areas follow these hygienic methods the protein loss due to parasitic infections can be prevented. Moreover the owner should be made aware of these infections by parasites. In future control programmes should be implemented by maintaining hygiene and sanitation of the domestic duck and their food.

\section{LITERATURE CITED}

ADANG, K. L., ONUJE, S.J., AJANUSI, O J., EZEALAR, A.U. and ABDU, P. A. 2008. Gastrointestinal Helminths of the Domestic Pigeons (Columba Livia domestica Gmelin, 1789 aves: Columbidae) in Zaria, Northern Nigeria. Science World Journal. 3(1): 33 - 37. 
AHMED, S. 1969. Survey on the type of helminths commonly found in the country ducks. Pakistan. J. Vet. Sci. 3: 110-112.

AKHTAR, H 1987. Gastrointestinal nematodes from domestic fowl. Bangladesh. J. Zool. 15(2): 155159.

BASU, A. K. 2012. The prevalence of intestinal helminthes in broiler chickens in Trinidad. Vet. Arhiv. 82: 591-597.

BEGUM, A., MUKUTMONI, M., AKTER, F. and SEHRIN, S. 2019. Occurrence of parasites in domestic ducks from rural areas of Narayanganj Bangladesh. J. Zool. 47(2):315-323.

ELAHI, A., ISLAM, R., HOSSAIN, M.S., MOHIUDDIN, K., MIKOLON, A., PAUL, S.K., HOSSEINI, P.R., DASZAK, P. and ALAM, M.S. 2014. Prevalence and diversity of avian haematozoan parasites in wetlands of Bangladesh. J Parasitol Res. vol. no. 1-12. 493754. doi: 10.1155/2014/493754.

EOM K. S. and RIM H. J. 1984. A study on the parasitic helminths of domest ducks (Anas platyrhynchos var.domestica Linneaus) in Korea. Korean J. Parasitol. 22(2): 215-221.

FARZANA, T., ISLAM, K.R. and MONDAL, M.M.H. 2008. Population density of helminths in ducks: effects of host's age, sex, breed and season. Bangl. J. Vet. Med. 6(1): 45-51.

HASSOUMI, T. and BELGHYTI, D. 2006. Distribution of gastrointestinal helminths in chicken farms in the Gharb region - Morocco. Parasitol. Res. 99: 181-183.

HUSSEN, H., CHAKA, H., DENEKE, Y. and BITEW, M. 2012. Gastrointestina helminths are highly prevalent in scavenging chickens of selected districts of eastern Shewa zone, Ethiopia. Pakistan J. of Biol. Sc. 15: 284-289.

ISLAM, M.A., ANISUZZAMAN, A.K., RABBI, M.A., RAHMAN A. and RAHMAN, M.H.A. 2013. Haemoproteus spp. infection of domestic poultry of Bangladesh. Vet Scan| Online Vet. Med. Res. 7 (2): 132-132.

ISLAM, M.R., SHAIKH, H. and BAKI, M.A. 1988. Prevalence and pathology of helminth parasites in domestic ducks of Bangladesh. Vet. Parasitol. 29: 73-77

JABBAR, M.A., RAHMAN, M.H., TALUKDER, R.K. and RAHA, S.K. 2007. Alternative institutional arrangements for contract farming in poultry production in Bangladesh and their impacts on equity, research report 7. ILRI, Nairobi.

KENNEDY, C. R. and BUSH, A. O. 1992. Species richness in helminth communities; the importance of multiple congeners. Parasitology 104: 189- 97.

KHANUM, H. 1974. Studies on some helminthes of domestic fowl of Dhaka city. M. Sc. Thesis. 1$163 \mathrm{pp}$.

KHANUM, H. (1997). Trematode parasite Paraphostomum humairum sp. from doemstic fowl of Bangladesh. Journal of Bengal Natural History Society. 16(2): 35-39.

MAGWISHA, H.B., KASSUKU, A.A., KYVSGAARD, N.C. and PERMIN, A. 2002. A comparison of the prevalence and burdens of helminth infections in growers and adult free-range chickens. Trop. Anim. Health Prod. 34: 205-214. 
MEKIBIB, B., DEJENE, H. and SHEFERAW, D. 2014. Gastrointestinal helminthes of scavenging chickens in outskirts of Hawassa, southern Eithiopia. Global Veterianaria 12(4): 557-561.

MOLlA, W., HAILE, H., ALMAW, G. and TEMESGEN, W. 2012. Gastrointestinal Helminthes of local backyard chickens in North Gondar Administrative Zone, Ethiopia. Revue Med. Vet. 7: 362 367.

MULDER, R. 2013. Aspects of security, safety and quality of sustainable poultry production. In: proceedings of the seminar, 8th international Poultry Show and Seminar 2013. World's Poultry Science Association, Bangladesh Branch. pp.31-33.

MUSA, S., RAHMAN, T. and KHANUM, H. 2012. Prevalence and intensity of parasites in domestic ducks. Dhaka Univ. J. Biol. Sci. 21(2): 197-199.

NAIR, K and NADAKAL, A.M. 1981. Hematological changes in domestic chicken infected with cestode Raillietina tetragona. Vet. Parasitol. 8: 49-58.

OJOK, L. 1993. Diseases as important factor affecting increased poultry production in uganda. Der Tropenlandwirt-Journal of Agriculture in the Tropics and Subtropics. 94: 37-44.

PUTTALAKSHMAMMA G. C., ANANDA, K. J., PRATHIUSH, P. R., MAMATHA, G. S. and SUGUNA, R. 2008. Prevalence of Gastrointestinal parasites of Poultry in and around Banglore. Veterinary World 1 (7): 201-202

QADIR, A. N. M. A. 1979. Helminth parasites of domestic ducks (Anas boschas domesticus) of Mymensingh district, Bangladesh. Bangladesh Veterinary Journal. 13: 43-45.

RABBI , A.K.M.A. and SARKAR, A.J. 1976. The prevalence of avian diseases in Bangladesh Agricultural University Farm. Bangladesh Vet. J. 10: 61- 66.

RABBI, A. K. M. A., ISLAM, A., MAJUMDER, S., ANISUZZAMAN, A., and RAHMAN, M. H. 2006. Gastrointestinal helminths infection in different types of poultry. Bangladesh J. Vet. Med. 4 (1): 13-18.

SHINDE, L., JADHAV, B. and LANKA, L. P. 2009. Ecological survey of endoparasites from alimentary canal of Gallus gallus domesticus at Bhokardan dist. Jalna (M.S.). Deccan Current Science 11:23-30.

SOULSBY E J L 1982. Helminths, Arthropods and Protozoa of Domesticated Animals (7th d). London :Baillere Tindall and Cassell Ltd. pp. 366-387.

YADAVA, A. K. and TANDON V. 1991. Helminth parasitism of domestic fowl (Gallus domesticus L.) in a subtropical high-rainfall area of India. Beitr. Trop. Landwiirtsch. Vet. Med. 29: 97-104.

YAMAGUTI, S. 1958 (a). Systema Helminthum. The Trematodes of Vertebrates. Vol. I. Interscience Publishers Inc. New York, USA. pp. 979.

YAMAGUTI, S. 1961. Systema Helminthum. The Nematodes of Vertebrates. Part I and II. Vol. III. Interscience Publishers Inc. New York, USA. 679

YAMAGUTTI, S. 1961. Systema Helminthum Vol. III The Cestode parasites of Vertebrates. Intersciences Publishers, New York. 
YOUSFI, F., SENOUCI, K., MEDJOUAL, I., DJELLIL, H., \& SLIMANE, T. H. 2013. Gastrointestinal helminths in the local chicken Gallus gallus domesticus Linnaeus, 1758) in traditional breeding of North Western Algeria. Biodiversity

Journal. 4 (1): 229-234.

(Manuscript received on 20 September 2020 revised on 01 October, 2020) 